\title{
Patterns of Tree Species Usage by Long-Horned Beetles (Coleoptera: Cerambycidae) in Fiji
}

Author(s): Hilda Waqa-Sakiti, Alan Stewart, Lukas Cizek, and Simon Hodge

Source: Pacific Science, 68(1):57-64. 2014.

Published By: University of Hawai'i Press

DOI: http://dx.doi.org/10.2984/68.1.5

URL: http://www.bioone.org/doi/full/10.2984/68.1.5

BioOne (www.bioone.org) is a nonprofit, online aggregation of core research in the biological, ecological, and environmental sciences. BioOne provides a sustainable online platform for over 170 journals and books published by nonprofit societies, associations, museums, institutions, and presses.

Your use of this PDF, the BioOne Web site, and all posted and associated content indicates your acceptance of BioOne's Terms of Use, available at www.bioone.org/page/ terms of use.

Usage of BioOne content is strictly limited to personal, educational, and non-commercial use. Commercial inquiries or rights and permissions requests should be directed to the individual publisher as copyright holder. 


\title{
Patterns of Tree Species Usage by Long-Horned Beetles (Coleoptera: Cerambycidae) in Fiji ${ }^{1}$
}

\author{
Hilda Waqa-Sakiti, ${ }^{2,7}$ Alan Stewart, ${ }^{3}$ Lukas Cizek, ${ }^{4}$ and Simon Hodge $e^{5,6}$
}

\begin{abstract}
This study investigated cerambycid long-horned beetles in a lowland tropical forest in Fiji and produced 18 new records of beetle-tree associations along with data on beetle phenology and development times. Beetles were reared from timber baits exposed for 1 month to ovipositing females in the Savura Forest Park, Viti Levu. Twelve native, locally common tree species representing 10 families were examined. For each tree, two baits consisting of $16 \mathrm{~kg}$ of freshly cut branches were exposed in each of four time periods between June 2008 and May 2009. Eighteen cerambycid species and 557 individual beetles were reared from the 96 baits, with three of the beetle species probably being undescribed. Ceresium was the most abundant genus, representing almost $90 \%$ of all individuals reared, with most adults emerging between 4 and 6 months after the timber baits were exposed. Seventeen of the 18 beetle species each emerged from timber belonging to a single tree species, although more rearing records are required to support the high level of host-plant specificity reported here.
\end{abstract}

Xylophagous insects compose a large proportion of total forest biodiversity and play an important role in vegetation dynamics and nutrient cycling in forest ecosystems (Okland et al. 1996, Siitonen 2001, Grove 2002). With $>35,000$ described species (e.g., Lawrence and Britton 1982, Galileo and Estaban-Duran 2010, Botero and Monne 2011), the coleopteran family Cerambycidae is among the most

\footnotetext{
${ }^{1}$ Funding for this project was provided by The Darwin Initiative, United Kingdom. Manuscript accepted 3 June 2013.

${ }^{2}$ Institute of Applied Sciences, University of the South Pacific, Suva, Fiji.

${ }^{3}$ Department of Biology and Environmental Science, University of Sussex, Falmer, United Kingdom.

${ }^{4}$ Biology Centre ASCR and Faculty of Science, University of South Bohemia, Ceske Budejovice, Czech Republic.

${ }^{5}$ School of Biological and Chemical Sciences, University of the South Pacific, Suva, Fiji.

${ }^{6}$ Faculty of Agriculture and Life Sciences, Lincoln University, Christchurch, New Zealand.

${ }^{7}$ Corresponding author (e-mail: sakitiwaqa_h@usp. ac.fj).
}

Pacific Science (2014), vol. 68, no. 1:57-64

doi: $10.2984 / 68.1 .5$

(C) 2014 by University of Hawai'i Press

All rights reserved important components of xylophagous insect diversity because most species feed on wood of live or dead trees and/or associated fungi. Studies on the ecology of cerambycids fall into two main areas: understanding the ecology of pest species important to forestry and agriculture (e.g., Nair 2007, Haavik et al. 2010) and conservation of rare and/or endemic species.

Determining the mechanisms behind host tree location, host acceptance, and the conditions required for successful larval development has been the subject of much entomological research (Campbell and Borden 2009). Various mechanisms of host location have been proposed, including long-distance responses to plant-released volatiles, random landing on sites, and the location of hosts (and mates) by responding to sex pheromones (Allison et al. 1994, Nehme et al. 2009). Growth and development of larvae are also related to the "quality" of the host timber colonized by the female beetles (e.g., Heijari et al. 2008, Michaud and Grant 2010). There are a number of cases of native species of cerambycids utilizing exotic timber tree species, as well as situations where introduced cerambycid species utilize native trees (Sugiura et al. 2008, $\mathrm{Hu}$ et al. 2009, Maier 2009). 
It has been suggested that strictly monophagous herbivorous insects are rare in tropical forests: speciose plant genera tend to dominate tropical floras on all spatial scales and most herbivores feed on several hosts that tend to be closely related congenerics (Novotny et al. 2002). Consequently, the level of overlap in host use by insect herbivores decreases with increasing phylogenetic distance between the host plants. Similarly, Novotny and Basset (2005) suggested that in the tropics only a minority of herbivore species feed on a single plant species when alternative congeneric hosts are available and concluded that the geographic ranges of herbivores tend to coincide with those of plant genera rather than with plant species.

A taxonomic revision of the Cerambycidae in Fiji was carried out in 1952 by Dillon and Dillon. A total of 120 species in the family was recorded from Fiji, with 106 endemic, 12 native, and two introduced species. Recently, four more species have been added to this family (Lingafelter 2007, Waqa and Lingafelter 2009). There is little information available regarding the biogeography and ecology of Fijian cerambycids, including the species of plants that are utilized, levels of dietary overlap, and the frequency of host specificity. The aim of this investigation was to use standardized baits consisting of freshly cut timber from 12 native Fijian tree species to identify which of these host plants are selected by Fijian cerambycids. By exposing the timber over four time periods throughout the year some information on seasonality was also obtained.

\section{MATERIALS AND METHODS}

The study was conducted in a mosaic of primary and secondary lowland rain forest in the Savura Forest Reserve, Naitasiri Province, Fiji ( $\left.18^{\circ} 04^{\prime} \mathrm{S}, 178^{\circ} 26^{\prime} \mathrm{E}\right)$. Nausori (Suva) Airport, located $14 \mathrm{~km}$ east of the study site, has a mean annual rainfall of $2,926 \mathrm{~mm}$ and a perhumidity index (Walsh 1992) of 20. However, the study site is likely to receive additional orographic rainfall because the Nausori Airport is located on the floodplain of Fiji's widest river, the Rewa. The climate may be best described as tropical wet to superwet
(Richards 1996). Topography is very uneven with steep slopes and ridges (Keppel et al. 2005). The reserve was established in 1963 and comprises 396.5 ha. Five hundred and sixty species of indigenous plants have been recorded from the reserve, and the forest is dominated by Myristica spp., Calophyllum spp., Garcinia spp., and tree ferns (Cyathea spp.) (Keppel et al. 2005).

Insects were reared from baits of freshly cut, live, healthy trees of 12 native tree species selected to represent species locally abundant in the reserve (see Table 1). A bait consisted of $16 \mathrm{~kg}$ of freshly cut branches $(5-20 \mathrm{~cm}$ diameter, 85-90 cm length) of a single tree species tied together with a rope. Each tree species was sampled using eight baits $(128 \mathrm{~kg}$ of wood). A total of 96 baits was exposed in 2008 and 2009 in four sampling periods: June 2008, September 2008, January 2009, and April 2009. Two baits per tree species were exposed to ovipositing beetles for 1 month in each sampling period. Baits were suspended in the canopy 10-15 $\mathrm{m}$ above ground in a crown of a tree of the same species as the timber constituting the bait.

After 1 month of exposure in the forest, the baits were collected, enclosed in tough black cloth cages, and placed in a shade house. Each cage had a single opening in the front to which was attached a transparent container partially filled with $80 \%$ ethanol. Emerging beetles were attracted to the light from the opening, fell into the container of ethanol, and were collected every fortnight for 6 months. All reared cerambycids were mounted and identified to genera and species by reference to Dillon and Dillon (1952) along with direct comparison with the collection of the Bishop Museum, Honolulu, Hawai'i.

\section{RESULTS}

\section{Cerambycid Fauna and Host Use}

In total, 557 individuals belonging to 18 species of Cerambycidae were reared from the 96 timber baits (composing 1,536 kg of wood of the 12 tree species). This produced a rearing success of one cerambycid individual and one additional species per 2.76 and $85 \mathrm{~kg}$ of wood, 
TABLE 1

Cerambycidae Reared from Timber Baits $(n=8)$ Exposed at Canopy Level in a Lowland Forest, Savura Forest Reserve, Viti Levu, Fiji

\begin{tabular}{|c|c|c|c|c|c|c|c|c|c|c|c|c|c|}
\hline \multirow[b]{2}{*}{ Beetle Species } & \multicolumn{13}{|c|}{ Bait Species ${ }^{a}$} \\
\hline & G. myr & T. cal & P. sp & E. $m a c$ & M. gra & F. vit & F. $f u l$ & S. mel & A. mac & G. cel & S. sp & M. cas & Total \\
\hline $\begin{array}{l}\text { Araespor } \\
\quad \text { undescribed sp. } 1\end{array}$ & 5 & - & - & - & - & - & - & - & - & - & - & - & 5 \\
\hline $\begin{array}{l}\text { Ceresium guttaticolle } \\
\text { (Fairmaire) }\end{array}$ & 57 & - & - & - & - & - & - & - & - & - & - & - & 57 \\
\hline $\begin{array}{l}\text { Ceresium scutellaris } \\
\text { Dillon \& Dillon }\end{array}$ & 376 & - & - & - & - & - & - & - & - & - & - & - & 376 \\
\hline $\begin{array}{l}\text { Ceresium vacillans } \\
\text { Dillon \& Dillon }\end{array}$ & - & - & - & - & - & - & - & 65 & - & - & - & - & 65 \\
\hline $\begin{array}{l}\text { Scituglaucytes muiri } \\
\text { (Gressitt) }\end{array}$ & - & - & - & - & - & - & - & - & - & - & 4 & - & 4 \\
\hline $\begin{array}{l}\text { Gracisybra flava } \\
\text { (Dillon \& } \\
\text { Dillon) }\end{array}$ & - & - & - & - & - & 2 & - & - & - & - & - & - & 2 \\
\hline $\begin{array}{l}\text { Hestimidius } \\
\text { bumeralis } \\
\text { Breuning }\end{array}$ & - & - & - & - & - & - & 1 & - & - & - & - & - & 1 \\
\hline $\begin{array}{l}\text { Oopsis velata Dillon } \\
\text { \& Dillon }\end{array}$ & - & - & - & - & - & - & 4 & - & - & - & - & - & 4 \\
\hline $\begin{array}{l}\text { Oopsis zitja Dillon } \\
\text { \& Dillon }\end{array}$ & - & - & - & - & - & - & - & - & - & 2 & - & - & 2 \\
\hline $\begin{array}{l}\text { Neosciadella } \\
\text { brunnipes Dillon } \\
\text { \& Dillon }\end{array}$ & - & - & - & - & - & 6 & - & - & - & - & - & - & 6 \\
\hline $\begin{array}{l}\text { Neosciadella inflexa } \\
\text { inflexa Dillon \& } \\
\text { Dillon }\end{array}$ & - & - & - & - & - & 15 & - & - & - & - & - & - & 15 \\
\hline $\begin{array}{l}\text { Neosciadella } \\
\quad \text { multivittata } \\
\text { Dillon \& Dillon }\end{array}$ & - & - & - & - & - & 2 & - & - & - & - & - & - & 2 \\
\hline $\begin{array}{l}\text { Neosciadella spixi } \\
\text { Dillon \& Dillon }\end{array}$ & - & - & - & - & - & 4 & - & - & - & - & - & - & 4 \\
\hline $\begin{array}{l}\text { Sormida cinerea } \\
\text { Dillon \& Dillon }\end{array}$ & - & - & - & - & - & - & - & - & 1 & - & - & - & 1 \\
\hline $\begin{array}{l}\text { Sormida maculicollis } \\
\text { (Thomson) }\end{array}$ & - & - & - & - & - & - & 1 & - & - & - & - & - & 1 \\
\hline $\begin{array}{l}\text { Sybroides howqua } \\
\text { Dillon \& Dillon }\end{array}$ & - & - & - & - & - & - & 8 & 2 & - & - & - & - & 10 \\
\hline $\begin{array}{l}\text { Sybroides } \\
\text { undescribed sp. } 1\end{array}$ & - & - & - & - & - & - & 1 & - & - & - & - & - & 1 \\
\hline $\begin{array}{l}\text { Sybroides } \\
\quad \text { undescribed sp. } 2\end{array}$ & - & - & - & - & - & - & - & 1 & - & - & - & - & 1 \\
\hline Numbers & 438 & 0 & 0 & 0 & 0 & 29 & 15 & 68 & 1 & 2 & 4 & 0 & 557 \\
\hline Species & & 0 & 0 & 0 & 0 & 5 & 5 & 3 & 1 & 1 & 1 & 0 & 18 \\
\hline $\begin{array}{l}\text { Emerged beetles } \\
\text { all families }\end{array}$ & 2,254 & 235 & 8 & 289 & 305 & 1,427 & 182 & 159 & 35 & 798 & 382 & 26 & 6,100 \\
\hline
\end{tabular}

a Tree species codes: G. myr, Garcinia myrtifolia A. C. Smith; T. cal, Trichospermum calyculatum Seeman; P. sp., Psychotria sp. A. Gray; E. mac, Endospermum macrophylum Muell \& Arg.; M. gra, Macaranga graeffeana Pax \& Hoffm.; F. vit, Ficus vitiensis Seeman; F. ful, Ficus fulvopilosa Summerhayes; S. mel, Serianthes melanesica Fosberg; A. mac, Agathis macrophylla Seeman, Benth \& Hook; G. cel, Gironierra celtidifolia Gaud. Voy. Bonite.; S. sp., Syzigium sp. Gaertn. Fruct. Sem.; M. cas, Myristica castenofolia A. Gray. 
respectively. Only seven of the 12 sampled tree species and 24 of the 96 baits produced at least one long-horned beetle (although all trees and baits produced beetles of other families [Tables 1 and 2]). Both Ficus species yielded five cerambycid species. Five tree genera, Endospermum, Macaranga, Myristica, Psychotria, and Trichospermum, yielded no cerambycids (Table 1).

All specimens were identified to species except for two in the genus Sybroides and five in genus Araespor, and we believe that these individuals probably represent three undescribed species. All of the species are likely to be endemic to the Fiji Islands with the single exception of Ceresium guttaticolle (Fairmaire, 1850), which also occurs in Tonga, Western Samoa, Vanuatu, and New Caledonia (Table 1).

Only five cerambycid species were represented by 10 or more individuals (Table 1 ). The samples were dominated by three species of the genus Ceresium (89\% of all reared individuals), and $C$. scutellaris was the most com- mon species, represented by 376 individuals (68\% of total). Only Sybroides howqua Dillon \& Dillon, 1952 was reared from two host plants: Ficus fulva and Serianthes melanesica. All of the remaining 17 beetle species were reared from only a single host (Table 1 ).

\section{Seasonality and Beetle Development Time}

There was considerable difference in the numbers of individuals and species emerging from baits exposed in the different time periods (Table 2). Whereas the 24 baits exposed in June-July 2008 yielded 377 individuals (68\% of all individuals) belonging to eight species (44\% of all species), the baits exposed in September 2008 yielded only 35 individuals and three species. The baits exposed in January 2009 yielded 141 individuals of 13 species (25\% and $72 \%$, respectively, of all individuals and species reared). Only four individuals $(<1 \%)$ of three cerambycid species $(6 \%)$ emerged from the baits exposed in April (Table 2).

TABLE 2

Total Cerambycidae Beetles Reared from Four Sets of Timber Baits Set at Quarterly Intervals during the Year (2008/2009) at Savura Forest Park, Fiji

\begin{tabular}{|c|c|c|c|c|c|}
\hline \multirow[b]{2}{*}{ Beetle sp. } & \multicolumn{5}{|c|}{ Bait Exposure Period } \\
\hline & Jun-Jul 08 & Sept.-Oct. 08 & Jan.- Feb. 09 & Apr.-May 09 & Total \\
\hline Araespor undescribed sp. 1 & - & - & 3 & 2 & 5 \\
\hline Ceresium guttaticolle & - & - & 57 & - & 57 \\
\hline Ceresium scutellaris & 329 & 31 & 16 & - & 376 \\
\hline Ceresium vacillans & 36 & - & 29 & - & 65 \\
\hline Scituglaucytes muiri & 2 & 2 & - & - & 4 \\
\hline Gracisybra flava & - & - & 2 & - & 2 \\
\hline Hestimidius bumeralis & - & - & 1 & - & 1 \\
\hline Neosciadella brunnipes & - & - & 6 & - & 6 \\
\hline Neosciadella inflexa inflexa & - & - & 14 & 1 & 15 \\
\hline Neosciadella multivittata & - & - & 2 & - & 2 \\
\hline Neosciadella spixi & - & - & 4 & - & 4 \\
\hline Oopsis velata & 1 & 2 & 1 & - & 4 \\
\hline Oopsis zitja & - & - & 2 & - & 2 \\
\hline Sormida cinerea & 1 & - & - & - & 1 \\
\hline Sormida maculicollis & - & - & - & 1 & 1 \\
\hline Sybroides bowqua & 6 & - & 4 & - & 10 \\
\hline Sybroides undescribed sp. 1 & 1 & - & - & - & 1 \\
\hline Sybroides undescribed sp. 2 & 1 & - & - & - & 1 \\
\hline Total individuals & 377 & 35 & 141 & 4 & 557 \\
\hline Species & 8 & 3 & 13 & 3 & 18 \\
\hline
\end{tabular}


TABLE 3

Emergence Patterns for Ceresium spp. in Monthly Intervals after Timber Baits Were Removed from Exposure in the Field

\begin{tabular}{|c|c|c|c|c|c|c|c|c|}
\hline \multirow[b]{2}{*}{ Host Plant } & \multirow[b]{2}{*}{ Ceresium spp. } & \multicolumn{7}{|c|}{ Months since Exposure } \\
\hline & & 1 & 2 & 3 & 4 & 5 & 6 & Total \\
\hline G. myrtifolia & C. scutellaris & 3 & 0 & 16 & 167 & 189 & 1 & 376 \\
\hline G. myrtifolia & C. guttaticollē & 0 & 0 & 0 & 55 & 2 & 0 & 57 \\
\hline S. melanesica & C. vacillans & 0 & 0 & 0 & 17 & 33 & 15 & 65 \\
\hline Total & & 3 & 0 & 16 & 239 & 224 & 16 & 498 \\
\hline
\end{tabular}

In terms of development times, useful information could be obtained only for the $\mathrm{Ce}$ resium species because these were by far the most abundant. Apart from a few individuals that emerged after only 1 month, the majority of Ceresium emerged 4 to 5 months after the baits were exposed (Table 3). The emergence of $C$. vacillans from $S$. melanesica appeared to be slightly more protracted: emergence occurred after 4 to 6 months.

\section{DISCUSSION}

The results provide rearing records of 18 species of Cerambycidae emerging from timber from seven species of native Fijian trees. We know of no previous work examining host use by Fijian Cerambycidae. Rearing success was low in comparison with similar studies performed in temperate woodland in Europe (Vodka et al. 2009) and in the Neotropics (Berkov and Tavakilian 1999), and the emergence of adult cerambycids was inconsistent across tree species, individual baits, and sampling periods.

Host specificity of the cerambycids in our survey was very nearly absolute; only one beetle species emerged from more than one tree species. However, caution is required because only five beetle species were recorded in numbers of 10 or more, so the apparent narrow host range is to some extent an artifact of low abundance and emergence from a small number of individual baits (Novotny and Basset 2000, Hulcr et al. 2007). Individuals of the same species reared from the same bait may represent offspring of a single female and should be counted as only a single host record to avoid pseudoreplication. Similarly, the host ranges may have been wider if more species of wood had been exposed (Morewood et al. 2003). However, even given the limitations of the data, there is some evidence for a degree of host specificity for those species that were recorded in numbers greater than 10 , because they all emerged from a single host species and all from at least three individual baits. The lack of overlap between the 10 cerambycid species emerging from the two species of Ficus is also interesting, but because only one of these species was recorded with more than 10 individuals it is again difficult to draw robust conclusions about host specificity.

The three species of Ceresium collected were the three most abundant species. This genus is distributed throughout the Southeast Asian region and represented in Fiji by at least 18 species (Dillon and Dillon 1952, Waqa and Lingafelter 2009). The biology, life history, and host plants of the various Ceresium species in Fiji are very poorly known. From studies in Papua New Guinea, at least five species of Ceresium, including Ceresium unicolor larvae, have been found in a broad suite of flowering plants from botanically unrelated families (Hawkeswood and Dauber 1990, Hawkeswood 1994). Many of the host plants of Ceresium species are hardwoods (e.g., Acacia [Mimosaceae] and Citrus [Rutaceae]), but some softwood shrubs (e.g., Lantana [Verbenaceae] and Casuarina [Casuarinaceae]) are also used, indicating that Ceresium species are able to 
utilize nonnative species as well as native plants (Hawkeswood and Dauber 1990). However, contrary to these reports indicating polyphagy, all three of the species of $\mathrm{Ce}$ resium collected in the current survey were reared from only a single host species, with two species, C. scutellaris and C. guttaticolle, emerging from the same host plant, Garcinia myrtifolia.

There were obvious differences in the numbers of individuals and species that emerged from the timber exposed at different times of year, although the seasonal patterns in numbers are almost all due to Ceresium (see Berkov and Tavakilian 1999, Berkov 2002). In this type of experiment, the emergent beetles represent the final phase of several processes: host location, host acceptance, oviposition by the female, successful larval development, and, finally, emergence of the adult beetle. In many cases only a singleton or two individuals emerged from a single bait. It is unlikely that a female cerambycid would lay only one or two eggs on a suitable host; these low numbers of emerging adults suggest that considerable mortality has occurred in the development stages. Thus, without knowing how many females actually visited the timber baits and how many eggs were laid, it is difficult to generalize about patterns of adult beetle activity through the year. However, the emergence of beetles from timbers does indicate that ovipositing females of these species were active at the time the baits were exposed. It is interesting that the 24 baits exposed in April/ May 2009 resulted in only four beetles, whereas the June/July baits in the previous year yielded 377 individuals. The phenology of Cerambycidae in Fiji requires more detailed and longer-term investigation, employing a range of trapping and observational techniques, to clarify these issues.

Only Ceresium species occurred in large enough numbers for meaningful analysis of development times, and each of these species emerged from only one species of timber, so no comparisons could be made regarding development times or the "nutritional quality" of the different host tree species. One point of interest is that the development times of 4-6 months mirror somewhat the separation of the two peaks of abundance produced by the seasonal differences in exposure time. If adults occur in distinct peaks of abundance in the field and are short-lived, then, assuming similar development times occur under natural conditions as observed in the cloth cages, these peaks are likely to be 5-6 months apart.

The early emergence of a small number of Ceresium beetles was surprising, but it is extremely unlikely that this was a result of contamination of the timber, because the wood came from live, healthy trees and was inspected for larval galleries during bait preparation and exposed the same day as cutting. Studies conducted in Panama (in which 663 cerambycid beetles from 33 species were reared) found that most cerambycids emerged between 2 and 4 months after oviposition, similar to the emergence times of the current study (L.C., unpubl. data).

The results of surveys of this kind might always be, to some extent, an artifact of the limitations of the sampling regime. We investigated only a single habitat (lowland rain forest), the fresh baits were exposed for a single duration (1 month), and a narrow range of bait species (12) was used compared with the number of tree species present in the forest (Keppel et al. 2005). Using more (or different) species of baits, allowing longer exposures, examining different decay stages of the timber, and by collecting in different native and plantation forests, we would undoubtedly extend our knowledge of host use of Fijian cerambycids. However, even given the limitations of the investigation, the study has produced an initial set of host-use records for 18 species of Cerambycidae, including three species that are probably undescribed, and provided some evidence that the activity of Fijian cerambycids may be highly seasonal. The data also highlight the extreme dominance of Ceresium scutellaris in the assemblage and the strong association of this species with a single host plant, Garcinia myrtifolia. Seventeen of the species recorded each emerged from only a single host plant. However, many more rearing records are required before unequivocal statements can be made regarding a general specificity of host use in the Fijian Cerambycidae. 


\section{ACKNOWLEDGMENTS}

The involvements of the following people have made this work possible: Professor Bill Aalbersberg, Professor Linton Winder, and Marika Tuiwawa. Thanks also to the field assistants Alivereti Naikatini, Senivalati Vido, Tokasaya Cakacaka, and Apaitia Liga and to Darren Mann and Elenor Slade (Oxford University, United Kingdom), who accompanied H.W. during her visit to the Czech Republic. Professor Vojtech Novotny (University of South Bohemia, Czech Republic) was involved in initial discussions regarding the timber bait experimental setup in Fiji. L.C. was supported by the Czech Science Foundation (P504/12/1952). Finally we wish to thank two anonymous reviewers for their highly insightful and helpful comments on an early draft of the manuscript.

\section{Literature Cited}

Allison, J. D., J. H. Borden, and S. L. Seybold. 1994. A review of the chemical ecology of the Cerambycidae (Coleoptera). Chemoecology 14:123-150.

Berkov, A. 2002. The impact of redefined species limits in Palame (Coleoptera: Cerambycidae: Lamiinae: Acanthocinini) on assessments of host, seasonal, and stratum specificity. Biol. J. Linn. Soc. 76:195-209.

Berkov, A., and G. Tavakilian. 1999. Host utilization of the Brazil nut family (Lecythidaceae) by sympatric wood-boring species of Palame (Coleoptera, Cerambycidae, Lamiinae, Acanthocinini). Biol. J. Linn. Soc. 67:181-198.

Botero, J. P., and M. L. Monne. 2011. Andraegoidus aurivillius: New species, synonymies and key to the species (Insecta: Coleoptera: Cerambycidae). Zootaxa 2780:57-62.

Campbell, S. A., and J. H. Borden. 2009. Additive and synergistic integration of multimodal cues of both hosts and non-hosts during host selection by woodboring insects. Oikos 118:553-563.

Dillon, L. S., and E. S. Dillon. 1952. Cerambycidae of the Fiji Islands. Bernice P. Bishop Mus. Bull. 206:1-114.
Galileo, M. H. M., and J. R. Estaban-Duran. 2010. New species of Desmiphorini (Coleoptera: Cerambycidae: Lamiinae) from the Reserva Biológica Alberto Manuel Brenes, Alajuela, San Ramón, Costa Rica. Span. J. Agric. Res. 8:1033-1036.

Grove, S. J. 2002. Saproxylic insect ecology and the sustainable management of forests. Annu. Rev. Ecol. Syst. 23:1-23.

Haavik, L., M. K. Fierke, and F. M. Stephen. 2010. Factors affecting suitability of Quercus rubra as hosts for Enaphalodes rufulus (Coleoptera: Cerambycidae). Environ. Entomol. 39:520-527.

Hawkeswood, T. J. 1994. Observations on the biology and host plants of the Australian longhorn beetle, Ceresium seminigrum Aurivillius (Coleoptera: Cerambycidae). G. Ital. Entomol. 7:5-10.

Hawkeswood, T. J., and D. Dauber. 1990. Observations on Ceresium pachymerum (Pascoe) (Coleoptera: Cerambycidae) from Papua New Guinea. Bull. Ann. Soc. R. Belge Entomol. 126:131-136.

Heijari, J., A. M. Nerg, P. Kainulaines, U. Noldt, T. Levula, H. Raitio, and J. K. Holopainen. 2008. Effect of long-term forest fertilization on Scot pine xylem quality and wood borer performance. J. Chem. Ecol. 34:26-31.

Hu, J., S. Angeli, S. Schultz, Y. Luo, and A. E. Hajek. 2009. Ecology and management of exotic and endemic Asian longhorned beetle Anoplophora glabripennis. Agric. For. Entomol. 11:359-375.

Hulcr, J., M. Mogia, B. Isua, and V. Novotny. 2007. Host specificity of ambrosia and bark beetles (Col., Curculionidae: Scolytinae and Platypodinae) in a New Guinea rainforest. Ecol. Entomol. 32:762-772.

Keppel, G., J. C. Navuso, A. Naikatini, N. T. Thomas, I. A. Rounds, T. A. Osborne, N. Batinamu, and E. Senivasa. 2005. Botanical diversity at Savura, a lowland rain forest site along the PABITRA Gateway Transect, Viti Levu, Fiji. Pac. Sci. 59:175-191.

Lawrence, J. F., and E. B. Britton. 1982. Australian beetles. 2nd ed. Melbourne University Press, Melbourne.

Lingafelter, S. W. 2007. Two new Distenia Lepeletier \& Serville from Fiji with a key 
to the known Melanesian species (Coleoptera: Cerambycidae: Disteniinae). Bishop Mus. Occas. Pap. 93:3-11.

Maier, C. T. 2009. Distributional and host record of Cerambycidae (Coleoptera) associated with Cupressaceae in New England, New York, and New Jersey. Proc. Entomol. Soc. Wash. 111:438-453.

Michaud, J. P., and A. K. Grant. 2010. Variation in fitness of the longhorned beetle, Dectes texanus, as a function of host plant. J. Insect Sci. 10:206.

Morewood, W. D., P. R. Neiner, J. R. McNeil, J. C. Sellmer, and K. Hoover. 2003. Oviposition preference and larval performance of Anoplophora glabripennis (Coleoptera: Cerambycidae) in four eastern North American hardwood tree species. Environ. Entomol. 32:1028-1034.

Nair, K. S. S. 2007. Tropical forest insect pests ecology, impact, and management. Cambridge University Press, Cambridge, United Kingdom.

Nehme, M. E., M. A. Keena, A. Zhang, T. C. Baker, and K. Hoover. 2009. Attraction of Anoplophora glabripennis to male-produced pheromone and plant volatiles. Environ. Entomol. 38:1745-1755.

Novotny, V., and Y. Basset. 2000. Rare species in communities of tropical insect herbivores: Pondering the mystery of singletons. Oikos 89:564-572.

. 2005. Host specificity of insect herbivores in tropical forests. Proc. R. Soc. Lond. B Biol. Sci. 272:1083-1090.
Novotny, V., Y. Basset, S. E. Miller, G. Weiblen, B. Bremer, L. Cizek, and P. Drozd. 2002. Low host specificity of herbivores in a tropical forest. Nature (Lond.) 413:841-844.

Okland, B., A. Bakke, S. Haagvar, and T. Kvamme. 1996. What factors influence the diversity of saproxylic beetles? A multiscaled study from a spruce forest in southern Norway. Biodivers. Conserv. 5:75-100.

Richards, P. W. 1996. The tropical rainforest. Cambridge University Press, Cambridge, United Kingdom.

Siitonen, J. 2001. Forest management, coarse woody debris and saproxylic organisms: Fennoscandian boreal forests as an example. Ecol. Bull. 49:11-41.

Sugiura, S., Y. Yamaura, and H. Makihara. 2008. Biological invasion into the nested assemblage of tree-beetle associations on the oceanic Ogasawara Islands. Biol. Invasions 10:1061-1071.

Vodka, S., M. Konvicka, and L. Cizek. 2009. Habitat preferences of oak-feeding xylophagous beetles in a temperate woodland: Implications for forest history and management. J. Insect Conserv. 13:553-562.

Walsh, R. P. D. 1992. Representation and classification of tropical climates for ecological purposes using the perhumidity index. Swansea Geogr. 24:109-129.

Waqa, H., and S. W. Lingafelter. 2009. New Fijian Callidiopini (Coleoptera: Cerambycidae). Bishop Mus. Occas. Pap. 106:3-15. 